\title{
PERALIHAN AGAMA DAN KEBEBASAN BERKEYAKINAN
}

\author{
Hamda Sulfinadia \\ Universitas Islam Negeri Imam Bonjol Padang \\ hamda.nursal@gmail.com
}

\begin{abstract}
This paper takes the topic of religious freedom. Freedom of belief when faced with the principle of freedom of religion promoted by the declaration of human rights cause differences in public perception. The formulation of freedom of religion can be understood by choosing or embracing a religion, out of a religion and no religion is the scope of freedom of religion. This also affects the law and the provision of transitional religious sanctions contrary to the principle of religious freedom which will affect the violation of human rights. The existence of clash between two interests is the author interested in discussing it further.This research is library research (literature study), with normative approach. Data collection is done by recording, reviewing and reviewing all information obtained from primary and secondary data. After the data collection process is complete, data selection, data grouping, and description process is the compilation of data into a narrative text. Then the data is analyzed qualitatively to get the conclusion.This research produces: 1) There is a difference of opinion of scholars related to the issue of religious transition. The majority of religious scholars believe that the case of religious transition into the hudud finger. This is due to the definite and permanent form of punishment and there is no chance for the ruler to forgive him. Meanwhile, according to Hanafiyah incase this transition case of religion on takzir jarimah, the consequences of death penalty is fixed and permanent, but there is an opportunity for the ruler to forgive him and forgive him; 2) For the murder of transitional people in the shari'ah of Islam is the replacement of religion accompanied by war. The war in the Islamic Shari'ah is a major crime that includes one of the crimes that disrupt the security of the state and damage the existing system.
\end{abstract}

Keywords: Apostasy, Freedom, Belief

\begin{abstract}
Abstrak
Tulisan ini mengambil topik kebebasan beragama. Kebebasan berkeyakinan apabila dihadapkan dengan prinsip kebebasan beragama yang diusung oleh deklarasi HAM menimbulkan perbedaan persepsi dalam masyarakat. Rumusan dari kebebasan beragama dapat dipahami dengan memilih atau menganut suatu agama, keluar dari suatu agama dan tidak beragama adalah cakupan dari kebebasan beragama. Hal ini juga berpengaruh terhadap hukum dan pemberian sanksi peralihan agama bertentangan dengan prinsip kebebasan beragama yang nantinya akan berimbas pada pelanggaran hak asasi manusia. Adanya perbenturan antara dua kepentingan inilah penulis tertarik membahasnya lebih lanjut. Penelitian ini merupakan library research (studi kepustakaan), dengan pendekatan normatif. Pengumpulan data dilakukan dengan cara mencatat, mengkaji dan menela'ah semua informasi yang diperoleh dari data
\end{abstract}

FOKUS : Jurnal Kajian Keislaman dan Kemasyarakatan Vol. 3, No. 1, 2018

P3M Sekolah Tinggi Agama Islam Negeri (STAIN) Curup - Bengkulu

Available online: http://journal.staincurup.ac.id/index.php/JF

p-ISSN 2548-334X, e-ISSN 2548-3358 
primer dan skunder. Setelah proses pengumpulan data selesai, dilakukan seleksi data, pengelompokan data, kemudian proses deskripsi yaitu penyusunan data menjadi sebuah teks naratif. Kemudian data tersebut dianalisis secara kualitatif untuk mendapatkan kesimpulan. Penelitian ini menghasilkan: 1)terjadi perbedaan pendapat ulama terkait dengan persoalan peralihan agama. Mayoritas ulama berpendapat kasus peralihan agama masuk ke dalam jarimah hudud. Hal ini disebabkan karena bentuk hukuman pasti dan permanen dan tidak ada peluang bagi bagi penguasa untuk memaafkannya. Sedangkan menurut Hanafiyah memasukan kasus peralihan agama ini pada jarimah takzir, konsekwensi hukuman mati itu sudah pasti dan permanen, tapi ada peluang bagi penguasa untuk memaafkannya dan mengampuninya; 2) sebab dibunuhnya orang peralihan agama dalam syari'at Islam adalah penggantian agama yang disertai dengan peperangan. Sedang peperangan dalam syari'at Islam merupakan kejahatan besar yang termasuk salah satu kejahatan yang mengganggu keamanan negara dan merusak sistem yang ada.

Kata Kunci: Peralihan agama, Kebebasan, Berkeyakinan

\section{PENDAHULUAN}

Manusia, pada hakikatnya secara kodrati dianugerahi hak-hak dasar yang sama oleh Allah SWT. Hak-hak dasar ini disebut Hak Asasi Manusia (HAM). Hak asasi manusia sebagai anugerah Allah, yang melekat pada diri manusia, bersifat kodrati, universal serta abadi, berkaitan dengan harkat dan martabat manusia. Pada gilirannya, hak-hak dasar yang dibawa manusia sejak lahir inilah yang menjadi hak asasi manusia yang mempunyai pengaruh terhadap hak-hak dan kewajiban lainnya.

Konsepsi HAM itu bermula dari sebuah naskah Magna Charta, tahun 1215, di Inggris, dan yang kini berlaku secara universal mengacu pada Deklarasi Universal HAM (DUHAM), yang diproklamasikan PBB, 10 Desember 1948. Pada deklarasi ini dinyatakan bahwa setiap orang punya kebebasan pikiran, hati nurani, dan agama.

Padahal, kalau mau bicara jujur serta mengaca pada sejarah, sesungguhnya semenjak Nabi Muhammad SAW memperoleh kenabiannya (abad ke-7 Masehi, atau sekitar lima ratus tahun/lima abad sebelum Magna Charta lahir), sudah dikenalkan HAM serta dilaksanakan dan ditegakkannya dalam Islam. Atas dasar ini, tidaklah berlebihan kiranya bila sesungguhnya konsepsi HAM dalam Islam telah lebih dahulu lahir ketimbang konsepsi HAM versi Barat. Bahkan secara formulatif, 
konsepsi HAM dalam Islam lebih lengkap dari konsepsi HAM universal. Adapun fokus tulisan ini adalah; 1) pendapat Mazhab tentang peralihan agama; 2) penyebab dibunuhnya peralihan agama dalam hukum Islam; 3) kebebasan berkeyakinan menurut al-Qur'an.

Penelitian terdahulu yang terkait dengan kebebasan beragama di antaranya adalah: 1) kebebasan Beragama dalam Negara Pancasila, oleh Manunggal K.Wardana 2016; 2) hak Asasi Manusia di Indonesia: Sebuah Tinjauan Terhadap Perlindungan Kebebasan Beragama di Indonesia, oleh Martin Luther; 3) ekspresi Keberagamaan Masy. Islam Indonesia (Mozaik Kebinekaan Indonesia, oleh Fahrurrozi). Ketiga tulisan di atas membahas kebebasan bergama dari sudut pandang hukum positif. Sedangkan tulisan ini membahasnya dari sudut pandang hukum Islam.

\section{PEMBAHASAN}

\section{Pengertian Peralihan agama, Hukum, dan Sanksinya}

Kata peralihan agama merupakan bentuk isim fa'il dari kata يرتد - ارتد - ارتداد, dan bentuk mashdar-nya al-riddah (الردة). Riddah secara bahasa berarti الرجوع عن الثيء إلى غيره , kembali dari sesuatu ke sesuatu yang lain. ${ }^{l}$ Sedangkan menurut istilah, riddah sebagaimana yang dikemukakan oleh Abdul Qadir Audah Riddah adalah: Keluar dari agama Islam atau memutuskan (keluar) dari agama Islam. ${ }^{2}$ Definisi yang lebih lengkap dikemukakan oleh Wahbah al-Zuhailiy berikut ini:

Riddah adalah keluar dari Islam menjadi kafir, baik dengan niat maupun dengan melakukan tindakan atau berucap yang menjadikan kafir, baik ucapan itu dengan cara berolok-olok, melakukan perlawanan maupun mengiktikadkannya. ${ }^{3}$

Berdasarkan definisi di atas dapat dipahami bahwa peralihan agama itu adalah orang yang keluar dari agama Islam dan kembali kepada

\footnotetext{
1 Al-Khalil n-Nahwiy, "Al-Mu'jam al-A'rabiy al-Muyassar", (Tunis: Alesco, 1993), hlm. 199.

${ }_{2}$ Abd al-Qadir Audah, "Al-Tasyri' al-Jina'I”, (Beirut: Muasasah al-Risalah, 1996), Juz II, hlm. 706.

${ }^{3}$ Wahbah al-Zuhiliy, "Al-Fiqh al-Islamiy wa Adilatuh", (Damsyiq: Dar al-Fikr, 1989), juz VI, hlm. 183.
} 
kekafiran yang dilakukan dengan beberapa cara. Pertama, dengan perbuatan atau bersikap tidak mau melakukan sesuatu. Keluar dari Islam dengan perbuatan terjadi apabila seseorang melakukan perbuatan yang diharamkan Islam dengan menganggapnya boleh atau tidak haram, baik dilakukan dengan sengaja atau dengan melecehkan agama Islam dengan menunjukkan kesombongannya. Contoh menyembah berhala, matahari dan bintang. Kedua, dengan ucapan atau perkataan adalah keengganan seseorang untuk melakukan perbuatan yang diwajibkan oleh agama Islam, dengan diiringi keyakinan bahwa perbuatan itu tidak wajib. Atau seluruh perkataan yang bisa membawa seseorang keluar dari Islam. Contoh seperti keengganan melaksanakan shalat, zakat, puasa atau haji, karena semuanya itu dianggap tidak wajib. Ketiga, keluar dari Islam bisa juga terjadi dengan i'tikad atau keyakinan yang tidak sesuai dengan akidah Islam, seperti menganggap ada yang lebih kuasa dari Allah SWT atau Nabi Muhammad berbohong, Ali sebagai Nabi dan sebagainya. ${ }^{4}$

\section{Peralihan agama Perspektif al-Qur'an dan Hadis Surah al-Baqarah (2) : 217}

Ayat ini menjelaskan siapa yang keluar dari agamanya sebagaimana firman Allah dalam surat al-Kahfi (18): 64 adalah فارتنا . Firman Allah: , فيمت و هو كافر dalam keadaan kafir, sebelum sempat bertaubat dari kekafirannya, maka mereka itulah yang terhapus amalannya. Maksud dari firman-Nya: batal أولنك , yakni mereka yang peralihan agama dari agamanya dan mati dalam keadaan kafir, mereka adalah penghuni neraka yang kekal di dalamnya, dan ini yang dimaksud dengan kalimat hum fiha khalidu. ${ }^{5}$

Berdasarkan uraian di atas dapat dipahami bahwa ayat di atas menjelaskan orang yang kembali ke agama mereka setelah beriman (Islam) atau peralihan agama, apabila ia mati dalam keadaan kafir sebelum sempat taubat dari kakafirannya, maka amal ibadahnya sia-sia

\footnotetext{
${ }^{4}$ Ibid., dan Abd al- Qadir Audah, op.cit., hlm. 707

5 Abu Ja'far Muhammad bin Jarir at-Thabari, 'Jami' al-Bayan an-Ta'wil Ayi alQur'an”, (Beirut: Dar al-Fikr, 1995), juz 5, hlm. 586
} 
atau terbuang percuma, dan mereka itu penghuni neraka dan kekal di dalamnya.

\section{Surah Ali Imran (3) : 149}

QS. Ali Imran (3): 149 memberikan peringatan bagi orang-orang yang beriman agar tidak mengikuti orang-orang yang kembali kafir, karena hal ini akan mengakibatkan kegagalan atau merugi dalam urusan dunia dan akhirat dan Allah-lah sebaik-baik pelindung dan sebaik-baik penolong. ${ }^{6}$

\section{Surah Muhammad (47): 25}

Maksud dari ungkapan sesungguhnya orang-orang yang kembali ke belakang dalam surah Muhammad (47); 25, yaitu pada kekafiran yakni orang peralihan agama atau kembali ke belakang untuk mundur dan menghindar dari peperangan sesudah jelas bagi mereka petunjuk yang telah disampaikan Allah SWT melalui Rasulnya. Pada hakekatnya, setan yang terkutuk sesungguhnya jauh dari kebaikan telah memperindah dan mempermudah mereka untuk melakukan dosa dan pelanggaran dan setan itu juga memanjangkan angan-angan mereka.

Keperalihan agamaan disebabkan karena sesungguhnya mereka berkata dengan penuh keyakinan kepada orang-orang yang benci terhadap apa yang diturunkan Allah yakni orang-orang Yahudi dari kelompok Bani an-Nadhir dan Quraidzah atau kaum musyrikin Mekah yang mempunyai hubungan dengan musuh-musuh Islam di Madinah yaitu perjanjian, yang isinya: kami berjanji akan mematuhi kamu dalam beberapa urusan antara lain tidak ikut perang sebagaimana yang dianjurkan Nabi Muhammad, mereka menyatakan hal itu pada hal Allah senantiasa mengetahui semua rahasia-rahasia mereka.

Ibn Asyur mengilustrasikan ulah setan itu bahwa mengajak manusia yang jelas baginya petunjuk agar mereka mengikuti orang-orang peralihan agama musyrik dan kafir dalam beberapa persoalan sambil meyakinkan bahwa persetujuan itu tidak bertentangan dengan hidayah

${ }^{6}$ Ibid., juz VIII, h. 256 dan lihat juga M. Quraish Shihab, "Tafsir al-Misbah Pesan, Kesan dan Keserasian al-Qur'an”, (Jakarta: Lentera hati, 2002), Vol. II, hlm. 241 
yang mereka ketahui. Lalu mereka menyetujui dan mengikutinya, mereka merasakan kelezatannya sehingga sedikit demi sedikit mereka kembali kepada kekafiran dan akhirnya peralihan agama. ${ }^{7}$

\section{Surah Ali Imran (3) : 72-73}

Terkait dengan surah Ali Imran 72-73 ini ada beberapa riwayat di antaranya: ${ }^{8}$ Pertama, al-Hasan bin Yahya menceritakan kepada kami, ia berkata Abdurrazaq mengabarkan kepada kami ia berkata: Ma'mar mengabarkan kepada kami tentang firman Allah:

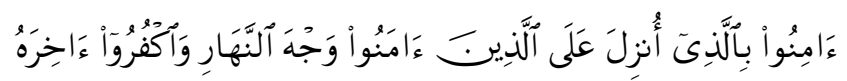

Seolah-olah perlihatkanlah seolah-olah kamu beriman kepada apa yang diturunkan kepada orang-orang beriman (sahabat-sahabat dan rasul) pada permulaan siang dan ingkarilah pada akhirnya.

Ayat di atas menggambarkan bahwa sebagian mereka berkata pada sebagian yang lain jadikanlah mereka senang dengan menampakkan agama mereka pada awal siang, karena hal itu lebih menginginkan mereka untuk mempercayai kalian, sementara kalian telah melihat apaapa yang kalian benci di antara mereka dan hal ini memungkinkan mereka untuk meninggalkan agama mereka.

Kedua, Muhammad bin al-Husain menceritakan kepada kami bahwa ada ulama Yahudi di perkampungan Arab ketika itu jumlahnya 12 orang, mereka berkata pada yang lain, masuklah kalian ke dalam agama Muhammad pada awal siang dan katakanlah : kami bersaksi bahwa Muhammad adalah hak dan benar dan jika tiba akhir malam, maka ingkarilah dan ucapkanlah: bahwa kami bertanya pada ulama ami, lalu mereka menjawab bahwa Muhammad itu pendusta dan kalian tidaklah di atas kebenaran sedikitpun. Katakanlah: bahwa kami telah kembali kepada agama kami, karena ia lebih menarik dari agama kalian. Lalu kemudian turunlah 2 ayat di atas, yang menjelaskan ancaman Allah kepada mereka, yang ditegaskan bahwa Demi Allah sesungguhnya telah kafir, yakni telah

\footnotetext{
${ }^{7}$ Ibid., hlm. 149

${ }^{8}$ Abu Ja'far Muhammad bin Jarir at-Thabari, Juz V, Op.cit., hlm. 472-473
} 
menutupi hakikat kebenaran sehingga pelakunya tidak dinilai penganut agama yang benar.

Ayat-ayat yang senada tersebut seluruhnya jelas tidak menyebutkan sanksi dunia bagi orang peralihan agama sama sekali, tidak ada hukuman mati, atau yang lebih ringan dari itu sekalipun. Sebab sesungguhnya hukum al-Quran adalah hukum yang memiliki prinsip kemudahan (takhfif) dan kasih sayang (rahmah), hukum yang menegaskan, menjamin dan memelihara adanya kebebasan berakidah, hukum yang mempertegas bahwa keimanan dan kekufuran adalah wilayah pribadi dan masalah privasi antara seseorang dengan Tuhannya. Sesungguhnya sanksi atau hukuman bagi kekufuran dan keperalihan agamaan setelah iman adalah hak Allah yang akan ditimpakannya di akhirat saja. Terkait dengan masalah ini, Allah-lah Sang Pemilik pertama dan terakhir.

Al-Quran melalui ayat-ayatnya telah menjelaskan kekejian dan kebusukan tindakan dan dosa peralihan agama, dan menjelaskan pula bahwa siapa yang terjerumus ke dalam keperalihan agamaan, maka ia telah berada dalam wilayah kekufuran, maka ayat-ayat tersebut menjelaskannya tanpa menyebutkan adanya sanksi dan hukuman duniawi. Hadis dari Muaz bin Jabal (Bulugh al-Maram, Hadis No. 986) ${ }^{9}$

Diriwayatkan dari Muadz bin Jabal ra. tentang orang yang masuk Islam kemudian memeluk agama Yahudi. "Aku tidak akan duduk sebelum dia dibunuh, keputusan Allah dan rasul-Nya lalu diperintahkan untuk membunuhnya dan dia dibunuh. (HR. Muttafaq 'alaih).

Begitu juga hadis dari Ibnu Mas'ud:

$$
\begin{aligned}
& \text { لا يحل دم امرئ مسلم يشهد أن لا إله إلا الله و أني رسول الله إلا باحدى ثلاث النفس بالنفس } \\
& \text { و الثيب الز اني و المارق من الدين التلرك الجماعة ـ ـ (رواه متفق عليه ) }
\end{aligned}
$$

Darah orang Islam yang bersaksi bahwa tiada Tuhan selain Allah tidak halal, kecuali karena salah satu dari tiga perkara, yaitu menghilangkan nyawa seseorang (membunuh), orang yang sudah

\footnotetext{
${ }^{9}$ Ibnu Hajar al-Asqalani, "Bulugh al-Maram”, (Bandung: Sygma Publishing, 2011), hadis No. 986, hlm. 559
} 
menikah berzina dan orang yang keluar dari agama meninggalkan jama'ahnya. (HR. Mutafaq 'Alaih).

Hadis-hadis di atas menjadi dalil wajib dibunuh bagi orang yang peralihan agama, dan ini sudah menjadi kesepakatan ulama. ${ }^{10}$ Terjadi perbedaan pendapat hanyalah dalam masalah apakah wajib diminta taubat terlebih dahulu atau tidak? Menurut pendapat mayoritas ulama wajib diminta taubat terlebih dahulu berdasarkan riwayat Abu Daud sebagai berikut ini:

$$
11 \text { و كان قد استتيب قبل ذلك . (رو اه أبو داود ) }
$$

Orang itu telah disuruh bertobat sebelumnya. (HR. Abu daud).

Hadis ini meriwayatkan bahwa orang yang peralihan agama tersebut telah diajak taubat oleh Abu Musa selama 20 hari untuk kembali ke Islam. Begitu juga dengan Muadz yang mengajak orang tersebut kembali ke Islam, tapi ia tidak mau dan akhirnya dipenggal lehernya. ${ }^{12}$ Sedangkan menurut al-Hasan dan ulama Zhahiri, tidak wajib diminta tobat terlebih dahulu terhadap orang yang peralihan agama, tapi ia harus dibunuh ketika itu juga, karena ia beralasan dengan hadis berikut ini:

$$
\text { فاقتلوه .(رواه البخارى (ابنى عله عنهما قال : قال رسول الله صلى الله عليه وسلم : من بدل دينه }
$$

Dari ibnu Abbas ra.bahwa Rasulullah SAW bersabda, "siapa yang berganti agama bunuhlah dia. (HR. Bukhari).

Huruf $f a$ pada kata فاقتلوه menunjukkan pada pengertian proses sesudahnya sebagaimana yang telah jelas dalam hadis di atas. Jadi, setelah ia peralihan agama, boleh dibunuh. Juga dengan alasan bahwa hukum

\footnotetext{
${ }^{10}$ Muhammad bin Ismail al-Kahlani, "Subul al-Salam”, (Mesir: Mustafa al-baby al-Halay, 1960), hlm. 264

${ }^{11}$ Nabi SAW. Mengutus Abu Musa ke Yaman yang kemudian diikuti oleh Muadz bin Jabal. Ketika sampai di tempat yang dituju ia disambut dan dipapah. Ia berkata pada orang yang memapahnya: Turunlah. Ternyata orang itu adalah orang yang tidak dapat dipercaya. Siapa ini? Yang lain menjawab dia adalah orang Yahudi kemudian masuk Islam dan kembali ke Yahudi. Ibid., hadis No. 987, hlm. 560

${ }^{12}$ Muhammad bin Ismail al-Kahlani, loc.cit.

${ }^{13}$ Ibid., hlm. 265
} 
orang yang peralihan agama sama dengan hukum orang kafir harbi, di mana dakwah itu telah sampai kepada mereka, sehingga boleh diperangi tanpa harus diajak terlebih dahulu untuk kembali ke Islam. ${ }^{14}$

Hadis ini menjadi dalil wajibnya membunuh orang peralihan agama (mengganti agamanya), seperti yang dijelaskan di atas. Terkait dengan peralihan agama laki-laki, ulama sudah ijmak, sedangkan untuk peralihan agama perempuan masih terjadi perbedaan pendapat. Menurut pendapat mayoritas ulama, wajib dibunuh wanita yang peralihan agama itu, sebab kata s pada hadis di atas berlaku umum bagi laki-laki dan wanita.

Mereka juga beralasan dengan riwayat Ibnu Munzir dari Ibnu Abbas bahwa Abu Bakar ra. membunuh wanita yang peralihan agama pada masa kekhalifahannya. Padahal para sahabat banyak yang mengetahui dan tidak ada satupun yang menentangnya. ${ }^{15}$ Sedangkan menurut Imam Abu Hanifah sebagaimana yang dikutip oleh Ahmad Fathi Bahnisi dalam kitabnya bahwa wanita yang peralihan agama tidak dibunuh, tapi ditakzir (penjara). Alasannya adalah Rasulullah SAW melarang membunuh wanita tatkala melihat wanita terbunuh, seraya Beliau bersabda: Kenapa wanita ini dibunuh? (HR. Ahmad). Namun alasan Abu Hanifah dibantah oleh Jumhur, bahwa yang dilarang Rasulullah SAW dengan bahwa larangan itu hanyalah terhadap orang kafir asli bukan wanita peralihan agama. $^{16}$

Begitu juga dengan hadis dari 'Aisyah yang dijadikan alasan bahwa orang peralihan agama itu diancam hukuman bunuh: ${ }^{17}$

Hukum bunuh bagi pelaku peralihan agama bukanlah satu-satunya pendapat dalan khasanah hukum Islam. Hal ini dapat dilihat pendapat Umar bin Khattab tentang hadis من بدل دينه dikategorikan sebagai keputusan Rasulullah SAW sebagai kepala Negara, bukan fatwa dan

${ }^{14}$ Ibid., hlm. 266

${ }^{15}$ Muhammad bin Ismail al-Kahlani, op.cit., hlm. 267

${ }^{16}$ Ahmad Fathi Bahnisi, Al-Mausu'ah al-Jinayah, (Beirut: Dar al-Nahdhah al'Arabiyah, tt), hlm. 128 dan lihat juga Muhammad bin Ismail al-kahlani, op. cit., hlm. 269

${ }^{17}$ Muhammad ibn Ali asy-Syaukani, "Nail al-Authar", (Saudi Arabia: Idarah alBuhuts al-Ilmiah, tt), hlm. 146 
syari'at dari Allah SWT yang harus diikuti umat Islam dalam segala zaman, situasi, dan kondisi. ${ }^{18}$

\section{Konsep Islam tentang Hak Asasi Manusia}

Hak asasi manusia merupakan kebutuhan dan tuntutan setiap manusia yang paling mendasar yang mesti dipenuhi agar dapat menikmati hidup dengan baik. Hal ini disebabkan karena hak asasi manusia adalah hak fundamental yang dimiliki manusia berdasarkan kodratnya, yang secara moral dapat dibenarkan untuk menjunjung tinggi harkat kemanusiaan sehingga dapat mengembangkan kepribadiannya. ${ }^{19}$

Piagam Madinah merupakan naskah tertua dalam Islam yang berkaitan dengan hak asasi manusia. Naskah tersebut merupakan perjanjian antara umat muslim dengan non muslim, khususnya Yahudi yang dibuat sekitar tahun $624 \mathrm{M}$. Ada beberapa hak asasi manusia yang tertera di dalam piagam tersebut seperti kebebasan beragama yang disertai dengan persamaan hak, sebagaimana yang disebutkan dalam pasal 16: Kaum Yahudi yang mengikuti kami akan memperoleh pertolongan dan persamaan hak serta akan terhindar dari perbuatan yang aniaya dan merugikan. ${ }^{20}$ Bahkan persamaan hak antara laki-laki dan perempuan disebutkan dengan jelas dalam pasal 18: keikutsertaan wanita dalam berperang dengan kami dilakukan secara bergiliran. ${ }^{21}$

Kebebasan manusia adalah salah satu dari berbagai nilai mulia yang juga merupakan tujuan utama dari maqasid syari'ah. Bahkan bisa jadi secara khusus, yang fungsi paling penting untuk adanya iman dan tauhid adalah membebaskan manusia dari penghambaan kepada sesama makhluk dan membebaskannya dari khurafat-khurafat serta dari bentuk-bentuk penyembahan berhala (watsaniyyah) lainnya, dan menyampaikannya kepada Allah. Artinya tidak ada yang ditakuti selain Allah, tidak meminta

${ }^{18}$ Yusuf al-Qaradhawi, "Jarimah al-Riddah wa 'Uqubah al-Peralihan agama $f i$ Dhhau'I al-Qur'an wa al-Sunnah”, (Kairo: Dar ash-Shahwah, 1993), hlm.156-157

19 Baharuddin Lopa, "Al-Qur'an dan Hak Asasi Manusia", (Yogyakarta: PT. Dana Bhakti Prima Yasa, 1996), hlm. 1

${ }^{20}$ Munawir Sjadzali, "Islam dan Tata Negara”, (Jakarta: UI Press, 1990), hlm. 12

${ }^{21}$ Ibid. 
pertolongan kecuali hanya kepada Allah, dan menyerahkan dirinya secara total kepada-Nya.

Pada abad ke-19, sebagai akibat dari perkembangan sosialisme di Barat serta desakan rakyat, terdapat beberapa piagam yang dikeluarkan oleh daulah Usmaniah sebagai suatu reformasi. Pada tahun 1839, Sultan Abdul Majid mengeluarkan Hatt-I Syarif Gulhane (Piagam Gulhane), di dalamnya disebutkan asas praduga tak bersalah, jaminan atas kehormatan, hak atas milik dan lain-lain. ${ }^{22}$ Kemudian untuk memperkuat hak-hak yang tercantum dalam Piagam Gulhane, pada tahun 1856 dikeluarkan hatt-I Humayun (Piagam Humayun), di antara isinya mendeklarasikan kebebasan beragama. ${ }^{23}$

Pada abad ke-20, deklarasi Islam tentang hak-hak asasi manusia mencapai klimaksnya, ketika diundangkan al-Bayan al-Alami 'an alHuquq al-Insan fi al-Islam (Deklarasi Universal tentang Hak -Hak Asasi Manusia dalam Islam) di Paris pada tanggal 19 September 1981. Deklarasi ini sebenarnya juga merupakan upaya mempertegas identitas HAM versi Islam sebagai bentuk penolakan HAM universal dalam Piagam HAM PBB yang dinilai bias kepentingan Dunia Barat. ${ }^{24}$ Rumusan dalam deklarasi ini memuat sejumlah modifikasi materi dan intervensi nilai terhadap HAM tidak boleh bertentangan dengan ketentuan atau hukum yang ditetapkan Tuhan (huhud Allah) ${ }^{25} \mathrm{Hal}$ ini terlihat jelas dalam pengantar deklarasinya:

Hak-hak asasi dalam Islam bersumberkan dari suatu kepercayaan bahwa Allah, dan hanya Allah pemberi Hukum dan sumber dari segala hak -hak asasi manusia. Oleh karena bersumber dari Tuhan, maka tidak seorang pun pemerintah, majelis atau ahli yang bisa

${ }^{22}$ Harun Nasution, "Pembaharuan dalam Islam”, (Jakarta: Bulan Bintang, 1990), hlm.99-100

${ }^{23}$ Ibid.

${ }^{24}$ Definisi HAM seperti yang dikemukakan oleh Komisi HAM PBB adalah hakhak yang melekat pada manusia, dimana tanpa hak itu manusia tidak dapat hidup sebagai manusia. Lihat Baharuddin Lopa, loc.cit.

${ }^{25}$ Muhammad Tolchah Hasan, "Hak-hak Asasi manusia dan Pluralisme Agama: Tinjauan Kultural dan Teologi Islam dalam Anshari Thayib (Ed), HAM dan Pluralisme Agama”, (Jakarta: Pusat Kajian Strategi dan Kebijakan, 1997), hlm. 77 
membatasi atau melanggar dengan cara apa pun hak asasi yang telah dianugerahi Allah. Demikian pula hak-hak tersebut tak dapat dilepaskan dari manusia.

Allah SWT telah menurunkan berbagai ayat yang melegitimasi kebebasan ini, menjaga dan menjaminnya, serta menganggapnya sebagai substansi kemanusiaan yang jika kebebasan ini lenyap, maka lenyap pula peranan manusia dalam seluruh eksistensinya. Allah menjelaskan bahwa penyembahan dan penghambaan manusia kepada-Nya adalah merupakan pembebasan dan kemuliaan, bukan malah merendahkan derajat kemanusiaan dan menghinakannya seperti dijelaskan dalan surah al-Nahl (16): 73-78.

Selanjutnya, untuk menandai permulaan abad ke-15 Era Islam, bulan September 1981, di Paris (Perancis), telah diproklamasikan Deklarasi HAM Islam Sedunia. Deklarasi ini berdasarkan Kitab Suci al-Qur`an dan as-Sunnah serta telah dicanangkan oleh para sarjana muslim, ahli hukum, dan para perwakilan pergerakan Islam di seluruh dunia.

Deklarasi HAM Islam Sedunia itu terdiri dari Pembukaan dan 22 macam hak-hak asasi manusia yang harus ditegakkan, yakni mencakup : 1) hak hidup; 2) hak kemerdekaan; 3) hak persamaan dan larangan terhadap adanya diskriminasi yang tidak terizinkan; 4) hak mendapatkan keadilan; 5) hak mendapatkan proses hukum yang adil; 6) hak mendapatkan perlindungan dari penyalahan kekuasaan; 7) hak mendapatkan perlindungan dari penyiksaan; 8) hak mendapatkan perlindungan atau kehormatan dan nama baik; 9) hak memperoleh suaka; 10) hak-hak minoritas; 11) hak dan kewajiban untuk berpartisipasi dalam pelaksanaan dan manajemen urusan publik; 12) hak kebebasan percaya, berpikir dan berbicara; 13) hak kebebasan beragama; 14) hak berserikat bebas; 15) hak ekonomi dan hak berkembang darinya; 16) hak mendapatkan perlindungan atas harta benda; 17) hak status dan martabat pekerja dan buruh; 18) hak membentuk sebuah keluarga dan masalahmasalahnya; 19) hak-hak wanita yang sudah menikah; 20) hak mendapatkan pendidikan; 21) hak menikmati keleluasaan pribadi 
privacy); 22) hak mendapatkan kebebasan berpindah dan bertempat tinggal. ${ }^{26}$

Menurut Syekh Syaukat Hussain, HAM yang dijamin oleh agama Islam dapat diklasifikasikan ke dalam dua kategori, yaitu : 1) HAM dasar yang telah diletakkan oleh Islam bagi seseorang sebagai manusia; dan 2) HAM yang dianugerahkan oleh Islam bagi kelompok rakyat yang berbeda dalam situasi tertentu, status, posisi dan lain-lainnya yang mereka miliki. Hak-hak asasi manusia khusus bagi non muslim, kaum wanita, buruh/pekerja, anak-anak, dan lainnya merupakan beberapa contoh dari kategori hak asasi manusia-hak asasi manusia ini.

Hak-hak dasar yang terdapat dalam HAM menurut Islam ialah : 1) Hak Hidup; 2) Hak-hak Milik; 3) Hak Perlindungan Kehormatan; 4) Hak Keamanan dan Kesucian Kehidupan Pribadi; 5) Hak Keamanan Kemerdekaan Pribadi; 6) Hak Perlindungan dari Hukuman Penjara yang Sewenang-wenang; 7) Hak untuk Memprotes Kelaliman (Tirani); 8) Hak Kebebasan Ekspresi; 9) Hak Kebebasan Hati Nurani dan Keyakinan; 10) Hak Kebebasan Berserikat; 11) Hak Kebebasan Berpindah; 12) Hak Persamaan Hak dalam Hukum; 13) Hak Mendapatkan Keadilan; 14) Hak Mendapatkan Kebutuhan Dasar Hidup Manusia; dan 15) Hak Mendapatkan Pendidikan. ${ }^{27}$

Al-Qur'an pun telah mengukuhkan kebebasan manusia yang paling tinggi dan paling penting serta memiliki posisi paling istimewa untuk dilestarikan adalah kebebasan berkeyakinan dan berakidah (huryah al 'aqidah), kemudian kebebasan berpendapat dan berekspresi (huryah al ta'bir), dan selanjutnya kebebasan-kebebasan lain yang menjadi simbol kemanusiaan manusia (insaniyat al insan). ${ }^{28}$ Dengan kata lain, al-Quran telah menegaskan bahwa kebebasan berakidah, kebebasan berpendapat

\footnotetext{
${ }^{26}$ http://re-searchengines.com/0805arief4.html

${ }^{27}$ Syekh Syaukat Hussain, "Human Rights in Islam", (New Delhi : 1996), hlm. $54-7$.

28 Wahbah al-Zuhailiy, "Haqq al-Huriyah fi al-Alam", (Penerjemah Ahmad Minan dan Salafuddin Ilyas), (Jakarta: Pustaka al-Kautsar, 2005), hlm. 137-140.
} 
dan kebebasan berkreasi dan berekspresi serta kebebasan-kebebasan lainnya merupakan hak asasi manusia yang dijamin dan harus dijaga.

Terkait dengan keharusan untuk menjaga dan melestarikan seluruh kebebasan manusia ini biasanya disejajarkan dengan nilai-nilai tauhid (al-tauhid), penyucian jiwa (al-tazkiyyah), dan kemakmuran (al-'umran). Hal ini juga berkaitan erat dengan maqasid syari'ah, seperti; keadilan (al'adalah), kebebasan (al-hurriyah), persamaan (al-musawah), dan lainlain. Banyak ayat al-Quran yang menegaskan secara khusus adanya kebebasan berakidah dan larangan adanya paksaan dalam menentukan pilihan akidahnya atau mengubah apa yang telah menjadi keyakinannya. Al-Quran juga menegaskan bahwa akidah merupakan hak khusus dan progratif masing-masing, serta merupakan daerah privacy antara seseorang dengan Tuhannya. Oleh karena itu tidak ada seorang pun yang boleh memaksakan akidah dan keyakinannya kepada orang lain atau merubah akidahnya atas nama apapun dan dalam keadaan apapun.

Kebebasan berakidah ini dijamin berbagai ayat al-Quran yang satu sama lainnya saling menguatkan bahwa hak asasi mausia yang satu ini wajib dijaga dan dilestarikan serta dijauhkan dari campur tangan pihak luar. Hal ini tertera dalam surah al-Baqarah (2) ayat : 256, bahwa tidak ada paksaan untuk memeluk agama Islam.

Asbab an-nuzul ayat ini adalah: Abu Daud, an-Nasaiy, Ibnu Hibban, dan Ibnu Jarir dari Ibnu Abbas, ia berkata: “Ada seorang wanita yang tidak memiliki seorang anak laki-laki pun yang hidup, sehingga ia berjanji jika memiliki anak laki-laki yang hidup, maka ia akan menjadikannya sebagai seorang Yahudi. Ketika Bani Nadhir dikunjungi, di antara mereka terdapat anak-anak kaum Anshar. Mereka berkata: "Jangan ajak anakanak laki-laki kami." Kemudian Allah menurunkan ayat "Laa Ikraaha fi al Diin (Tidak ada paksaan dalam agama)."29

Kebebasan berakidah dijamin oleh Islam, begitu banyak ayat alQur'an yang dianggapnya sebagai kebebasan absolut sesuai dengan pilihan masing-masing yang tidak dibarengi dengan sanksi (had/hudud)

\footnotetext{
${ }^{29}$ Jalal al-Din Muhammad bin Ahmad al-Mahalliy dan Jalal al-Din Abdurrahman bin Abu Bakar al-Suyuti, “Tafsir al-Jalalain”, (Semarang: Usaha Keluarga, tt), hlm. 40
} 
apapun, dan tidak ada yang berhak mengadakan perhitungan apapun kecuali Allah.

Sebagian para ahli telah menjelaskan sikap al-Qur'an terhadap dua jenis kafir; pertama, terhadap kafir asli (orang yang menjadikan kekufuran sebagai pilihan pertamanya) dan tidak berusaha (berkeinginan) untuk pindah keyakinan. Kedua terhadap orang yang kufur setelah sebelumnya menjatuhkan pilihan dalam keimanan. Al-Quran mentolerir kebebasan pilihan bagi yang pertama, dan menentang kebebasan pilihan bagi yang kedua. Sebagaimana Allah berfirman dalam surah al-Baqarah (2) ayat 108-109.

\section{Relevansi Larangan Peralihan Agama dengan Kebebasan Beragama}

Nash-nash yang menunjukkan ketetapan kebebasan beragama ada dua: 1) nash-nash yang melarang memaksakan suatu agama;2) nash-nash yang terkait dengan membela kebebasan beragama. ${ }^{30}$ Pertama, nash-nash yang melarang memaksakan agama. Terdapat banyak nash yang secara jelas menetapkan larangan memaksakan suatu agama atau keyakinan, dan melarang memaksa masuk Islam dengan menggunakan cara paksaan apapun. Hal ini sejalan dengan persyaratan kebebasan memilih dalam sahnya Islam dan sesuai dengan logika sesuatu serta tabiat agama. Di antara nash-nash yang dimaksud tersebut adalah ayat-ayat al-Qur'an yang menjadi undang-undang umat islam dalam hukum berintegrasi dengan umat lainnya, misalnya: Surah al-Baqarah (2): ayat 256 seperti yang telah dijelaskan pada uraian sebelumnya. Ayat ini melarang untuk memaksakan agama pada pemeluk agama lain, karena sesungguhnya pemaksaan itu dilarang secara syarak. Surah Yunus (10): ayat 99. Ayat ini adalah di antara ayat tentang pencelaan melakukan pemaksaan terhadap keimanan.

Lebih lanjut Surah al-Kahfi (18) : 29, memberikan penegasan terhadap keyakinan setelah turunnya al-Qur'an dan tetapnya Islam serta menjelasan dalil-dalil dan bukti-bukti mengenai asal akidah yang benar.

Setelah memperhatikan ayat-ayat di atas, dapat dipahami bahwa tidak perlu menghumus pedang atau memaksa orang untuk memeluk suatu

\footnotetext{
${ }^{30}$ Ibid ., hlm. 142-144.
} 
agama. Siapa yang memilih agama Islam ataupun kafir, ia harus bertanggung jawab atas pilihan tersebut. Siapa yang angkuh, sombong dan memilih kekafiran sebagai akidah, maka akan menempati neraka jahanam. Ini adalah balasan yang didasaran atas pilihan. Jadi tidak adil seandainya menyiksa seseorang atas sesuatu yang dipaksakan kepadanya.

Syariat Islam telah menetapkan dua cara menjaga kebebasan berkeyakinan yaitu: ${ }^{31} 1$ )mewajibkan manusia untuk menghormati hak-hak orang lain dalam meyakini sesuatu yang mereka kehendaki dan dalam meninggalkan sesuatu yang mereka inginkan, sesuai dengan aqidah mereka. Siapa pun tidak boleh memaksa orang lain agar merubah keyakinannya atau menyakininya karena melaksanakan ibadahnya; 2)mewajibkan para pemilik keyakinan untuk menjaga keyakinannya sendiri dan membelanya. Mereka diberi kebebasan untu berpindah dari negara lainnya jika tidak mampu menjaga dirinya baik untuk orang muslim maupun non muslim. Hal ini telah dijelaskan Allah dalam firmanNya dalam surah an-Nisa' ayat 97-98.

Ini adalah hukum yang jelas dan pasti bahwa Islam menetapkan kebebasan beragama bagi manusia dalam memilih keyakinan mereka, dan tidak ada jalan untuk memaksa seseorang. Siapa yang beriman, sesungguhnya ia beriman untuk dirinya sendiri dan menyelamatkan dirinya dari siksaan. Siapa yang ingkar dan menentang, sesungguhnya ia telah melemparkan dirinya dalam siksaan.

Kedua, nash-nash yang membela kebebasan beragama, di antaranya adalah: Surah al-Ghasyiyah ( 88 ): 21 yang menjelaskan untuk memberi peringatan pada orang-orang yang ingkar dan menentang, Surah al-An'am ( 6 ): 107, Surah al-Kafirun ( 109 ): 1-6.

Selain terkait dengan hal di atas, ada ayat-ayat yang mengajak untuk hidup rukun antar umat beragama, saling tukar kasih sayang, saling damai dengan orang-orang non muslim. Juga memerintahkan agar berhati-hati terhadap orang yang menyulut api permusuhan dan peperangan yaitu orang-orang Yahudi, musyrik dan para penyembah berhala, seperti yang dijelaskan dalam surah al-Maidah ( 5 ): ayat 82.

\footnotetext{
${ }^{31}$ Abdul Qadir 'Audah, op.cit., hlm. 31-33
} 
Wahbah al-Zuhailiy menjelaskan bahwa sebab dibunuhnya orang peralihan agama dalam syari'at Islam adalah penggantian agama yang disertai dengan peperangan. Sedang peperangan dalam syari'at Islam merupakan kejahatan besar yang termasuk salah satu kejahatan yang mengganggu keamanan negara dan merusak sistem yang ada. Oleh sebab itu penguasa muslim berhak dan bahkan berkewajiban untuk melindungi sistem sosial yang dijadikan landasan Negara Islam. ${ }^{32}$ Jika ada seseorang yang peralihan agama tanpa memerangi, tidak terang-terangan, tidak melecehkan umat Islam, tidak mengganggu Islam secara terbuka baik dalam pikiran, akidah, metode dan politik, maka tidak boleh dibunuh. Inilah yang dinamakan dengan kebebasan beragama dan menyerahkan hukuman atau sanksinya kepada Allah di akhirat nanti.

Akan tetapi bila orang peralihan agama tersebut bergabung dengan musuh dan memerangi umat Islam, dengan berada di pihak dar al-harbi, maka hukumnya adalah sebagaimana kafir harbi, negara atau pribadi boleh membunuhnya, mengambil hartanya, karena sudah menjadi musuh Islam. Hal ini disebabkan karena ia sudah tahu situasi, kondisi dan rahasia umat Islam. ${ }^{33}$

Begitu juga bila orang yang peralihan agama tadi sekelompok orang dan mereka memerangi Islam, maka semuanya harus dibunuh. Hal ini disebabkan karena mereka sudah menjadi ancaman bagi norma dan aturan Islam, yang dapat membuka celah perpecahan dalam Islam, yang biasanya akan diikuti dengan terbukanya celah-celah yang lain.

Kebebasan beragama atau berkeyakinan terdiri dari tiga unsur: ${ }^{34}$ 1)berpikir dengan bebas tanpa tunduk dengan taklid (peniruan), maka tidak sah Islam karena taqlid kepada seseorang para leluhur atau pemimpin; 2)larangan memaksakan keyakinan tertentu, baik dengan menyiksa atau menipu dengan keharaman dan kekejian; 3)bebas melakukan sesuatu yang sesuai dengan agamanya tanpa adanya tekanan yang melarangnya untuk mengungkapkan dan melaksanakan simbolsimbol keagamaannya.

\footnotetext{
${ }^{32}$ Ibid., hlm. 160.

${ }^{33}$ Ibid., hlm. 161.

${ }^{34}$ Wahbah al-Zuhailiy, Haq al-Huriyyah., op.cit., hlm. 141-142.
} 
Lebih lanjut dijelaskan oleh Wahbah al-Zuhailiy, bahwa tidak ada riwayat yang menyebutkan bahwa Nabi SAW membunuh orang-orang peralihan agama. Meskipun Rasulullah SAW dengan adanya wahyu, dapat mengetahui bahwa orang peralihan agama mempermainkan agama Islam dan Nabi pun tahu bahwa Islam tidak yang tertanam kuat dalam hatinya dan mereka kembali ke agama mereka semula (kafir), namun Nabi SAW tidak membunuh mereka. ${ }^{35}$ Teks-teks hadis yang memerintahkan membunuh orang peralihan agama adalah teks umum, bukan berarti karena Rasulullah SAW tidak mempraktekannya, tapi tidak bisa dipraktekan. Kalaupun ada riwayat yang menjelaskan Nabi SAW. pernah melakukan hukuman bunuh, itu disebabkan bukan karena peralihan agamanya, tapi ada faktor lain, di mana karena keperalihan agamaannya ia melakukan tindakan pemberontakan.

Secara filosofis prinsip kebebasan beragama yang dibawa oleh Islam, sejalan dengan karakter keberagaman yang sehat oleh manusia yang telah ditakdirkan sebagai makhluk yang mempunyai potensi memilih. Memaksa seseorang untuk menganut suatu keyakinan, justru tidak akan menghasilkan kualitas keberagaman yang baik, serta akan merendahkan derajad manusia yang mempunyai kemampuan memilih.

Indonesia sebagai negara majemuk, yang mengakui beberapa agama, yaitu Islam, Kristen Katolik, Protestan, Hindu, Budha dan Konghucu. Kebebasan beragama dan berkeyakinan telah diakui bangsa Indonesia sejak didirikannya negara Republik Indonesia. Pengakuan terhadap hak atas kebebasan beragama tercantum dalam pasal 29 (2) UUD 1945 yang menjamin kemerdekaan tiap-tiap penduduk untuk memeluk agamanya masing-masing. Pasal 2 tersebut di atas menyatakan bahwa peringatan keras dapat dilakukan dan sanksi berupa peringatan dan bahkan pembubaran jika dilakukan oleh organisasi. Setiap orang bebas memeluk agama dan beribadah menurut agamanya, memilih pendidikan dan pengajaran, memilih pekerjaan, memilih kewarganegaraan, memilih tempat tinggal di wilayah negara dan meninggalkannya, serta berhak kembali.

${ }^{35}$ Ibid. 


\section{PENUTUP}

Berdasarkan uraian di atas disimpulkan bahwa terjadi perbedaan pendapat ulama terkait dengan persoalan peralihan agama. Mayoritas ulama berpendapat kasus peralihan agama masuk ke dalam jarimah hudud. Hal ini disebabkan karena bentuk hukuman pasti dan permanen dan tidak ada peluang bagi penguasa untuk memaafkannya. Sedangkan menurut Hanafiyah memasukan kasus peralihan agama ini pada jarimah takzir, konsekwensi hukuman mati itu sudah pasti dan permanen, tapi ada peluang bagi penguasa untuk memaafkannya dan mengampuninya.

Sebab dibunuhnya orang peralihan agama dalam syari'at Islam adalah penggantian agama yang disertai dengan peperangan. Sedang peperangan dalam syari'at Islam merupakan kejahatan besar yang termasuk salah satu kejahatan yang mengganggu keamanan negara dan merusak sistem yang ada.

Al-Qur'an pun telah mengukuhkan kebebasan manusia yang paling tinggi dan paling penting serta memiliki posisi paling istimewa untuk dilestarikan adalah kebebasan berkeyakinan dan berakidah (huryah al'aqidah), kemudian kebebasan berpendapat dan berekspresi (huryah alta'bir), dan selanjutnya kebebasan-kebebasan lain yang menjadi simbol kemanusiaan manusia (insaniyat al- insan). Sesungguhnya paksaan tidak akan membentuk akidah yang baik, tetapi akan semakin menjauhkannya. Akidah tidak akan tenang dalam jiwa kecuali dengan kebebasan melalui akal.

\section{DAFTAR PUSTAKA}

Al-Asqalani, Ibnu Hajar. 2011. Bulugh al-Maram. Bandung: Sygma Publishing.

Al-Qaradhawi, Yusuf. 1993. Jarimah al-Riddah wa 'Uqubah alPeralihan agama fi Dhau'i al-Qur'an wa al-Sunnah. Kairo: Dar ash-Shahwah.

Al-Zuhailiy, Wahbah. 2005. Haqq al-Huriyah fi al-Islam. Penerjemah Ahmad Minan dan Salafuddin Ilyas. Jakarta: Pustaka al-Kautsar. 
Al-Zuhailiy, Wahbah. 1989. Al-Fiqh al-Islamiy wa Adilatuh. Damsyiq: Dar al-Fikr.

An-Nahwiy, Al-Khalil. 1993. Al-Mu'jam al-A'rabiy al-Muyassar. Tunis: Alesco.

Asy-Syaukani, Muhammad ibn Ali. Tt. Nail al-Authar. Saudi Arabia: Idarah al-Buhuts al-Ilmiah.

Audah, Abd al-Qadir. 1996. Al-Tasyrik al-Jina'I. Beirut: Mu'asasah alRisalah. Juz II.

Bahnisi, Ahmad Fathi. Tt. Al-Mausu'ah al-Jinayah. Beirut: Dar alNahdhah al-'Arabiyah.

Hasan, Muhammad Tolchah. 1997. Hak-hak Asasi manusia dan Pluralisme Agama: Tinjauan Kultural dan Teologi Islam dalam Anshari Thayib (Ed), HAM dan Pluralisme Agama. Jakarta: Pusat Kajian Strategi dan Kebijakan.

Hussain, Syekh Syaukat.1996. Human Rights in Islam. New Delhi: T.Tp.

Lopa, Baharuddin. 1996. Al-Qur'an dan Hak Asasi Manusia. Yogyakarta: PT. Dana Bhakti Prima Yasa.

Muhammad bin Jarir at-Thabari, Abu Ja'far. 1995. Jami' al-Bayan anTa'wil Ayi al-Qur'an. Beirut: Dar al-Fikr.

Muhammad bin Ismail Al-Kahlani. 1960. Subul al-Salam. Besir: Mustafa al-baby al-Halaby.

Nasution, Harun. 1990. Pembaharuan dalam Islam. Jakarta: Bulan Bintang.

Shihab, M. Quraish. 2002. Tafsir al-misbah Pesan, Kesan dan Keserasian al-Qur'an. Jakarta: Lentera hati.

Sjadzali, Munawir. 1990. Islam dan Tata Negara. Jakarta: UI Press. 